解説

\title{
新パワー半導体と周辺部品
}

\author{
舟木 剛 \\ 大阪大学大学院工学研究科電気電子情報工学専攻, 565-0871 吹田市山田丘 2-1.
}

\section{Novel Power Semiconductor Device and Peripheral Components}

\author{
Tsuyoshi FUNAKI
}

Div. Electrical, Electronic and Information Eng., Graduate School of Eng., Osaka University, 2-1 Yamada-oka, Suita 565-0871, Japan.

Received January 10, 2016; Revised March 23, 2016; Accepted March 24, 2016

\begin{abstract}
Power electronics have been attracting attention as an energy saving technology. The rated voltage and the operating frequency of the power conversion circuit have been increasing to attain higher efficiency, higher power density, and superior functionality. To this end, the conventional Si power semiconductor device have been developing, but the improvement approaches the theoretical limitation. Then, novel power semiconductor devices, which are essentially different from conventional Si power devices, have been researching and developing enthusiastically. They are unchartered territory for the conventional power electronics. Therefore, there are many difficult problems to solve. Power electronics is not an independent academic discipline, but it consist of number of engineering aspects; e.g. electronics engineering, electrical engineering, and control engineering. The recent progress of power electronics is led by the development of power device, but it cannot be realized without cooperation of peripheral components and fabrication technologies. This paper explains the precious technology, which is indispensable to fully utilize the performance of newly developed novel wide band gap power semiconductor device from the view point of peripheral component.
\end{abstract}

\section{KEY WORDS}

Power electronics, power semiconductor device, high voltage, high switching frequency, fast switching, passive component

\section{1 はじめに}

東北大震災に伴う原子力発電所の稼働停止を契機とした電 力エネルギー不足を背景に, パワーエレクトロニクスが省エ ネルギーを実現する技術として注目されるようになった。 パ ワーエレクトロニクス自体は電力エネルギーを生み出すもの ではなく, 入力された電力の電圧・電流を異なる電圧・電流 の電力に変換する技術である，しかし，ただ単に電力を変換 するだけでは，変換時に損失を生じるだけで省エネルギー効 果を得ることはできない. 損失少なく出力を取り出せる電源 の動作点と, 損失少なく運転できる負荷の動作点が必ずしも 一致しないことから, 電力変換により電源と負荷の両者それ ぞれに適した電圧・電流で動作させることで損失を低減し, システム全体としての動作効率を高めることがパワーエレク トロニクスの目的となる.またパワーエレクトロニクスは,

* Corresponding author, E-mail:funaki@eei.eng.osaka-u.ac.jp
単に電圧・電流の值だけでなく，直流と交流といった電気の 性質を変換することで様々な電源と負荷を接続することを可 能にする技術でもある．様々なアプリケーションに対してパ ワーエレクトロニクスを適用することで得られる省エネル ギー効果は大きいが，現在では更に高効率化することが望ま れている.このため, 電力変換の制御による動作点の最適化 だけでなく, 電力変換における変換損失までも低減する必要 がある。また鉄道車両や自動車などの移動体で用いるパワー エレクトロニクスでは, 電力変換装置の小型軽量化もシステ 厶全体の消費エネルギー低減につながる，電力変換における 損失を低減するために回路の高電圧・小電流化による導通損 失の低減や，高速スイッチング動作によるスイッチング損失 の低減, また高周波数スイッチング動作によるリアクトルや コンデンサ等の周辺部品の小型化を目指し，パワー半導体の 性能向上に向けて研究開発がすすめられている ${ }^{1)}$. ただし従 来の $\mathrm{Si}$ 半導体を用いた IGBTや MOSFET では, 高電圧化し 
た際の導通損失低減や，スイッチング動作の高速化が半導体 材料の物理的限界に到達しつつある。このため Si に比べて バンドギャップの大きい $\mathrm{SiC}$ や $\mathrm{GaN}$ を半導体材料に用いた パワーデバイスの開発が進められている ${ }^{21}$. しかしながらパ ワー半導体を取り換えただけで電力変換回路およびシステム 全体の性能は改善されない. 本稿では, パワーエレクトロニ クスのさらなる進化に向け, 新パワー半導体を適用した電力 変換回路における周辺部品のあり方について解説する.

\section{2 新パワー半導体の特長}

データシートに記載されている単体の性能が良い部品で も，その部品に見合った使い方をしなければ性能を引き出 すことはできない.ここでは，従来の $\mathrm{Si}$ パワー半導体に比 べて優れた性能を持っていると言われている $\mathrm{SiC} や \mathrm{GaN}$ と いった新パワー半導体について, $\mathrm{Si}$ パワー半導体に比べてど のような点が優れているのかについて述べ，それを電力変換 回路においてどのように引き出していけばよいかについて説 明する。

パワー半導体の耐圧 $V_{b d}$ は，(1) 式に示すように半導体材料 の破壊電界強度 $E_{c}$ とドープされた不純物濃度 $N_{d}$ で決まる. またパワーデバイスの耐圧層の抵抗 $R_{d}$ は, 耐圧 $V_{b d}$ の 2 乗に 比例し, 破壊電界強度 $E_{c}$ の 3 乗に反比例する ${ }^{3)}$.

$$
R_{d}=\frac{W_{d}}{\mu e N_{d} A}=\frac{4 V_{b d}^{2}}{\mu \varepsilon_{s} E_{c}^{3} A}
$$

ただし， $W_{d}$ : 空乏層幅， $\mu$ : キャリア移動度， $e$ : 単位電荷， $A$ : 面積, $\varepsilon_{s}:$ 誘電率である.

$\mathrm{Si}$ 半導体の破壊電界強度は $3 \mathrm{kV} / \mathrm{cm}$ 程度であり，耐圧が数

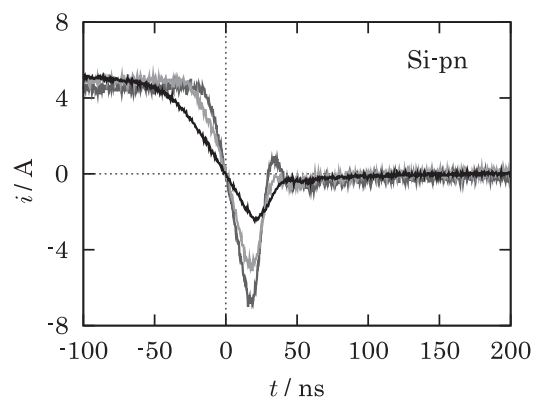

(a) Switching speed (di/dt) dependency
百 V 以上になると抵抗が顕著に増加し，導通損失が大きく なる．このため高耐圧の $\mathrm{Si}$ パワー半導体では，バイポーラ 構造を適用し，少数キャリア注入による電導度変調効果によ り導通損失を低減している。導通・遮断の定常状態では十分 な性能が得られるものの，スイッチングの過渡応答の特性が 犠牲となる. Fig. 1 はダイオードのターンオフにおける電流 の応答である. Si PiN ダイオードでは, ターンオフ時に逆回 復電流と呼ばれる逆方向に大きな電流が流れる。これは注入 された少数キャリアの処理に伴う現象であり，スイッチン グ損失の原因となる。特に Fig. 1 (a)に示すように順方向電 流を大きくしたり，Fig. 1 (b) に示すようにdi/dtを大きくし た高速スイッチング動作や，高温動作においてそのピーク 值は顕著に大きくなる. また Fig. 2 (a) は, Si IGBT のターン オフ動作におけるコレクタ電流の応答である. Fig. 2 (b) に示 すようにIGBT の等価回路は，Nチャネル MOSFET でベー スを駆動するPNPトランジスタとして表される．Nチャネ ル MOSFET は，PNPトランジスタのベースに電荷を注入す ることはできるが, ベースから電荷を引き抜くことはできな い.このためターンオフ時にはMOSFET 部の電流は高速に 減少するが, PNPトランジスタのベース部に残留したキャ リアが消滅するまで PNP トランジス夕部は導通を継続する。 これがテール電流となって現れるとともに，スイッチング損 失の原因となる. 以上のように, 高電圧の $\mathrm{Si}$ パワー半導体 は, スイッチング動作特性のために，高速・高周波数の動作 には問題があった。

さてバンドギャップの大きい $\mathrm{SiC}$ や $\mathrm{GaN}$ 等の半導体は, $\mathrm{Si}$ 半導体に比べて破壊電界強度が 1 桁以上大きい特長がある.

Fig. 1 Current response in turn off operation of Si PiN diode.



(a) Current response in turn off

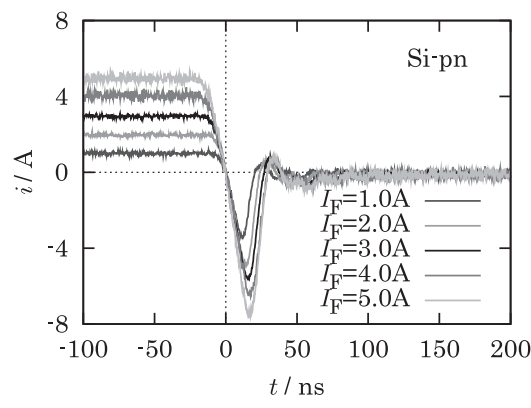

(b) Forward current $\left(\mathrm{I}_{\mathrm{F}}\right)$ dependency

Fig. 2 Si IGBT.



(b) Equivalent circuit 




(b) Switching speed (di/dt) dependency

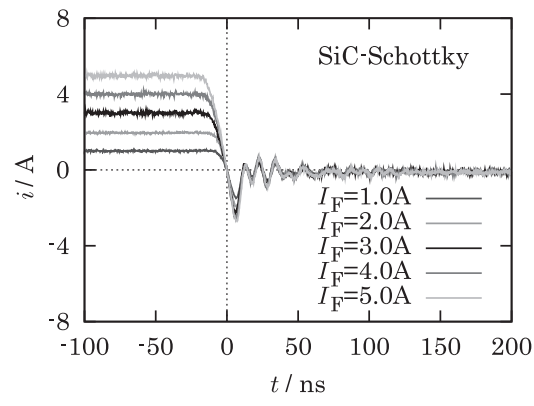

(b) Forward current $\left(\mathrm{I}_{\mathrm{F}}\right)$ dependency

Fig. 3 Current response in turn off operation of SiC SBD diode.

このため, 従来 $\mathrm{Si}$ 半導体では導通損失低減のためにバイポー ラ構造を適用していた高耐圧のデバイスに対しても，ユニ ポーラ構造が適用可能である. ユニポーラ構造のパワー半導 体は，ドープされた不純物による多数キャリアのみで導通動 作する.このためバイポーラ構造とは異なり，スイッチング 動作において少数キャリアの処理を必要としない. ただし, 遮断状態における空乏層形成のための多数キャリアの充放電 に要する動作は必要であり, これを零とすることはできない. Fig. 3 に示すダイオードのターンオフ動作では, 逆方向に流 れる電流が Si PiNダイオードに比べて大幅に小さくなって いることが分かる．スイッチング速度 di/dt 依存性や，順方 向電流 $\mathrm{I}_{\mathrm{F}}$ 依存性も小さい. また Fig. 4 に示す SiC MOSFET の ターンオフ動作におけるドレイン電流の応答には, IGBTに 見られるようなテール電流が生じていない. スイッチング動 作が速いことから，スイッチング損失も小さく抑えることが 可能である. このように, 新パワー半導体は高電圧の高速ス イッチング動作が可能であることに特長がある.すなわち, 新パワー半導体を適用することで, 高電圧・大容量の電力変 換回路の低損失化とともに動作の高周波数化が可能である.

\section{3 周辺部品に求められる要件}

前章では, 新パワー半導体の特長は, 高電圧の高速スイッ チング動作であることを述べた。 ただしパワー半導体のみで は電力変換動作を実現できず, リアクトルやコンデンサ等の 受動素子である周辺部品を組み合わせて用いる必要がある. 本章では, 新パワー半導体の性能を活かした電力変換回路に おいて周辺部品である受動素子に求められる要件について述 ベる.

\section{1 リアクトル}

DC-DC コンバータやDC-AC インバータにおいて，パワー 半導体のスイッチング動作で電流を導通・遮断するが, 電力 変換のために一時的にエネルギーをためておく要素としてリ アクトルが使われる，透磁率が高く，飽和磁束密度の高い磁 性材料をリアクトルの鉄心に用いることで, リアクトル全体 を小型化することが可能である. またスイッチング周波数を 高周波数化することも，リアクトルに必要なインダクタンス の值を小さくすることができ，小型化につながる．Fig. 5 に 各磁性材料のリアクトル鉄心として使用可能な周波数領域と

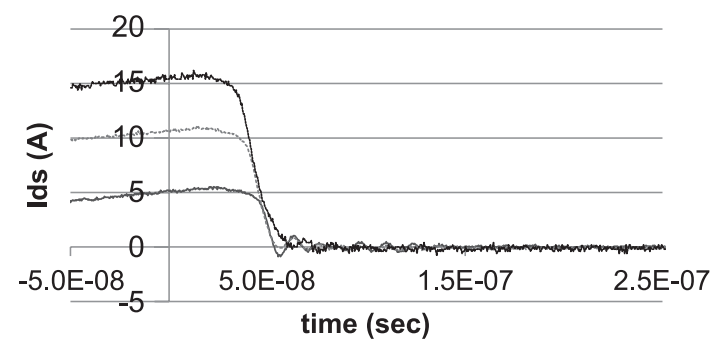

Fig. 4 Current response in turn off operation of SiC MOSFET.

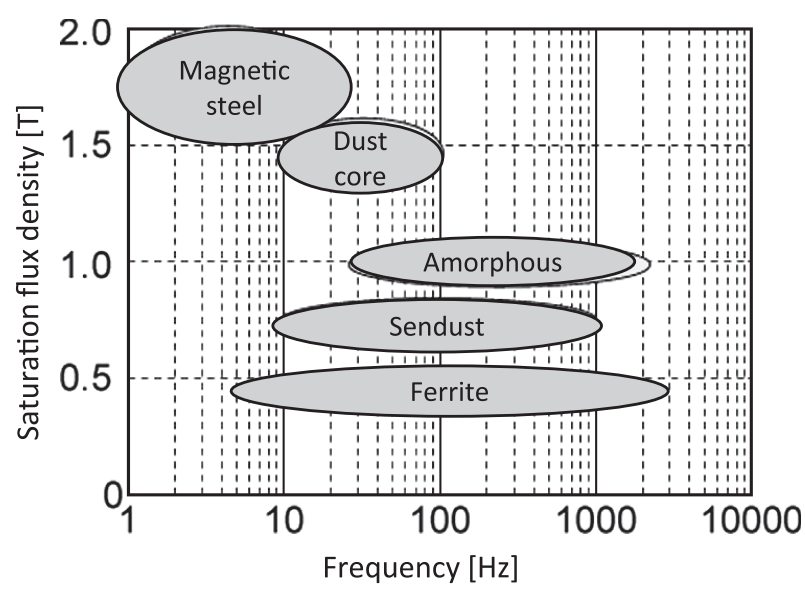

Fig. 5 Saturation flux density to frequency for magnetic materials.

飽和磁束密度の関係を示す ${ }^{4)}$. 同図は飽和磁束密度の高い材 料は，高周波数では鉄損が大きくなるために適用できず，逆 に高周波数で使用可能な材料は飽和磁束密度が低いことを示 している.このため, リアクトルの鉄心を小型化することを 目的として回路動作の高周波数化を図っても, 飽和磁束密度 の低い材料を使用せざるを得ず，磁路断面積が大きくしな り, 結果としてリアクトルは小さくならない.このため, 高 周波数スイッチング動作による電力変換器の小型軽量化を実 現するためには, 飽和磁束密度が高く, 高周波数での鉄損が 小さい磁性材料の開発が必要である。またDC-DCコンバー タに用いるリアクトルでは直流バイアス電流が印加された高 磁界下での使用も必要となる。この場合磁化特性が，交流印 加の場合とは異なるため, 高磁界下でも鉄損の増加が少ない 磁性材料が求められる. 粉体材料としてリアクトルの鉄心を 
考えた場合，焼結して鉄心形状を形成するのが一般的である. 圧力をかけて焼き固めることにより，粉体である鉄心材料の 充填率は高くなるものの，鉄心の抵抗率が低下する。このた め, 高周波数利用での渦電流損が大きくなる. したがって, 焼結しても抵抗率の下がらない粉体材料の開発が望まれる.

また高周波数での利用では, リアクトル鉄心の鉄損だけで なく、リアクトル巻線の銅損も問題となる．銅損の原因には 複数あり, 高周波数では表皮効果による交流抵抗の増加がそ の一つである。式(2)に示すように，表皮効果により交流電 流が流れることのできる導体表面からの深さ $d$ は周波数 $f$ の 平方根に反比例する ${ }^{5}$.

$$
d=\sqrt{\frac{\rho}{\pi f \mu_{m}}}
$$

ただし， $\rho$ : 導体の抵抗率， $\mu_{m}$ : 透磁率である.

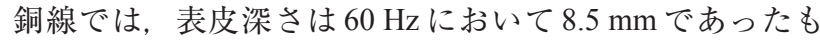
のが, $100 \mathrm{kHz} て ゙ は 0.2 \mathrm{~mm}$ となる。絶縁された細線を撚っ たリッツ線を使用することで表皮効果を低減することができ るが，導線間の間隙により占積率が小さくなる，銅損の他の 原因として巻線の近接効果がある. 特にリアクトルの各巻線 にながれる電流は，方向が同一となるため，近接した巻線に 流れる電流により誘導された渦電流により，巻線内の流れる 電流の偏りが生じて導通損失が増加する。また卷線間の寄生 静電容量は, リアクトルの自己共振を生じる原因となる。特 に小型化のために占積率を大きくして密卷線とすると, 寄生 容量が増加し，また自己共振周波数も低下するため高周波数 での使用を難しくする，以上のように，リアクトルをはじめ とする磁気部品は, 高周波数スイッチング動作による性能向 上に対して磁性材料㧍よび巻線の両面からの課題の解決を図 る必要がある。

\section{2 コンデンサ}

電力変換回路においてコンデンサは, 直流電圧リプルを除 去する平滑，高調波を低減するためのフィル夕，サージを吸 収するためのスナバとして使用されている。単相の DC-AC インバータでは, 交流の周波数の 2 倍の周波数で瞬時電力が 変動するため, 大きな静電容量の平滑コンデンサが必要とな る. 大容量の平滑コンデンサには, コス卜面で有利な電解コ ンデンサが利用されることが多い，三相インバータでは，各 相の瞬時電力の合計が一定となるため, 理想的には平滑コ ンデンサは必要としないが, 制御の遅れによる電圧変動を 避けるために比較的に大きな静電容量の平滑コンデンサが使 用されている，電解コンデンサは，等価直列抵抗による損失 が大きく, 電解液の蒸散による容量劣化掞よび寿命の問題が ある。このため特に信頼性の要求される電鉄や自動車を中 心に，フィルムコンデンサなどの他の種類のコンデンサの 採用が増えている．Fig. 6 にハイブリッド自動車のインバー 夕（PCU）の内部構造を示す. PCUに占める IGBT モジュー ルは比較的小さく, 平滑用のフィルムコンデンサが大きな部 分を占めていることが分かる.すなわちコンデンサの小型化 が，システム全体の小型化に大きく影響する。フフィルムコン デンサの小型軽量化として, 誘電体材料の薄膜化が進められ

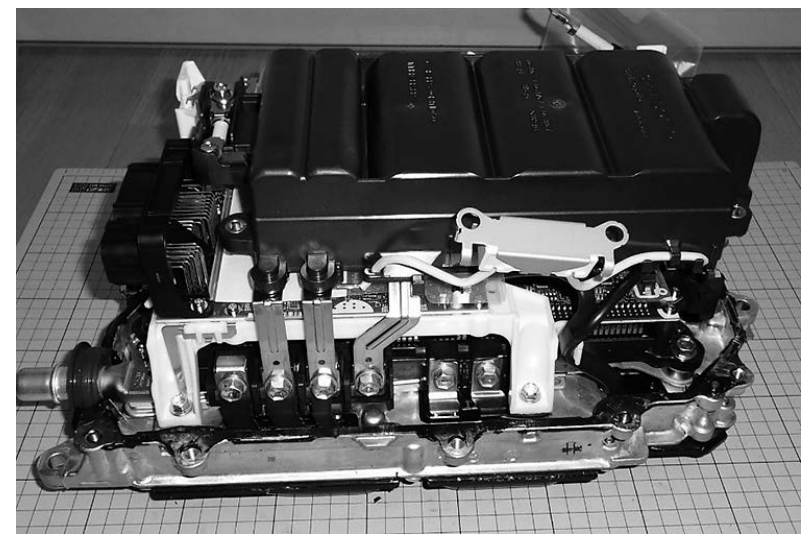

Fig. 6 PCU of HEV (Toyota Prius ZVW30).



Fig. 7 SiC DC-DC converter.

ているが，薄膜化によって誘電体に印加される電界強度が大 きくなることから, 品質と機能性の確保が課題となっている.

また最近は, 新パワー半導体を用いた小型・低損失・高温 動作によるモータドライブの機電一体化が進められており, コンデンサにも耐熱性能が要求されるようになってきた。こ のため過酷条件下でも使用可能なセラミックコンデンサの適 用も検討され始めている，七ラミックコンデンサは，小型大 容量, 高許容リプル電流, 高温動作可能といった特長がある が，一般的な $\mathrm{BaTiO} 3$ 材料を用いたコンデンサは直流バイア 又電圧印加時に静電容量が低下するとともに誘電損失も増加 するといった課題がある。 またセラミックコンデンサの端子 接合に用いられるハンダ材の温度サイクルに対する信頼性も 課題とされている. $\mathrm{SiC}$ パワー半導体を用いた DC-DCコン バータの平滑コンデンサにセラミックコンデンサを適用し， $200 \mathrm{kHz}$ の動作周波数で $143 \mathrm{~kW} / /$ を実現した報告がある ただし Fig. 7 に示すように小型のセラミックコンデンサを数 百個実装した構成となっており，信頼性には不安が残るもの となっている.

電力変換回路の平滑やサージ吸収用のセラミックコンデン サに適用する粉体材料として，印加電界による誘電率の変化 が少なくなるような性質が求められる。同時に損失低減のた めにも複素誘電率の虚数部も小さくなければならないととも に, より導電率の高い銅などの電極材料が適用できることが 望まれる。また高電圧化した場合に誘電体層を厚くしないた めにも, 破壊電界強度の向上も求められる. 


$$
4 \text { まとめ }
$$

本稿では, 新パワー半導体を適用したパワーエレクトロニ クスの方向性について述べた．新パワー半導体が目指してい る高電圧・高周波数スイッチング動作を適用したパワーエレ クトロニクスアプリケーションに対して，パワー半導体のみ を交換しても, 周辺部品に従来のものを使用していては電力 変換回路の性能向上を実現することは難しい，すなわち新パ ワー半導体を活かすも殺すも，周辺部品に依存するところが 大きい. 材料開発を含め, 周辺部品の性能向上が期待される.

\section{文献}

1) IGBT toshokikaku hennsyuuiinkai: Sekaiwo ugokasu power handoutai, ohmsha, (2008).

2) H. Matsumami et al.: Handoutai $\mathrm{SiC}$ gijyutsu to ouyou, Nikkankougyoushinnbun, (2011).
3) S. M. Sze: "Physics of semiconductor devices" $2^{\text {nd }}$ Edition, Wiley inter science, (1981).

4) Research committee of system integration of power electronics: Power electronics niokeru system integration gijyutsu, 1299 (2014).

5) N. Kumagai: Denjikigaku kisoron, ohmsha, (1987).

6) O. Kreutzer, et al.: "Full SiC DCDC-Converter with a Power Density of more than $100 \mathrm{~kW} / \mathrm{dm} 3$," Materials Science Forum, 821-823 (2015) 884-888. 